\title{
VALERIUS PATRUINUS' CASE \\ CONTRACTING IN THE NAME OF THE EMPEROR
}

By

\author{
WILLEM ZWALVE
}

\section{Introduction}

At some point in his early career, the praetorian prefect Valerius Patruinus ${ }^{1}$ was in charge of a vineyard as imperial procurator. ${ }^{2} \mathrm{He}$ had decided to sell it to a certain Stalticius subject to the usual condition that the sale was to be annulled if - at an auction to be held at a later time - another buyer was willing to pay a higher prize (in diem addictio). At the auction Stalticius turned out to be the highest bidder and the vineyard was consequently granted to him. The completion of this contract involved considerable difficulties. One of the problems was that the vineyard had been leased to an unknown farmer before it was sold to Stalticius. Roman law did not protect a lessee (conductor) against a transferee of the lessor (locator), so the farmer was now in danger of being ejected by the new owner. There was no privity of contract between the lessee and Stalticius and consequently the latter could eject the tenant at his discretion. However, if he did so, the lessor was liable to the lessee, because he was unable to fulfil his contractual duties to the tenant. In order to avoid liabilities of this kind, it was usual to stipulate in a sale of rented land that the buyer respected the rights of the tenant, ${ }^{3}$ but this seems to have been omitted in this case. Patruinus did his best to minimise the serious consequences of that mistake. His efforts on behalf of the imperial fiscus deserve some attention, as they may serve to illustrate the peculiar position of a procurator Caesaris, the ordinary representative of imperial power in civil cases.

\section{Common procurators and imperial procurators}

It is trite learning that the origin of the imperial 'administrative' (or 'managerial') procuratura is to be found in the common procuratores of Roman private law. ${ }^{4}$ As any wealthy Roman private individual did, the

\footnotetext{
${ }^{1}$ On Patruinus see SHA, Caracalla 4.2 and Cassius Dio 78.4.1a. Cf H.-G. Pflaum, Les carrières procuratoriennes équestres sous le Haut-Empire romain, supplément (Paris 1982), 57, nr. 220A (Valerius Patruinus).

${ }^{2}$ Dig. 49.14.50: "Valerius Patruinus procurator imperatoris".

${ }^{3}$ CJ 4.65 .9 (Alexander).

${ }^{4}$ Th. Mommsen, Das römische Staatsrecht III.1 (repr. Tübingen 1952), $557 \mathrm{ff}$; O. Hirschfeld, Die kaiserlichen Verwaltungsbeamte bis auf Diocletian (Berlin 1905), $411 \mathrm{ff}$; W. Eck, Die Verwaltung des
} 
emperor employed procurators in the management of his estates and other patrimonial interests as a matter of course. Now, whereas there is a substantial scholarly literature on the legal status of common Roman procurators ${ }^{5}$, there seems to be little or none at all on the civil status of imperial procurators. ${ }^{6}$ It seems as if the historians of Roman law, after having established the origins of the administrative procuratura, have lost interest and left that subject to historians. As a consequence, historians as well as legal historians may easily fail to notice the important difference between the legal status of imperial procurators and their counterparts in the private sector. Valerius Patruinus's case may serve as a good example. Before going into that, it is worth while to make some comments on the nature of his activities.

It is quite remarkable to find Patruinus in the business of freely disposing of imperial property: imperial estates are being let and sold at the discretion of the procurator, without intervention of the emperor. Clearly, imperial authority was not required to enable his procurator to dispose of them. There is a marked contrast here with the administration of praedia Caesaris under the stewardship of the procurator patrimonii. Ulpian emphasises that these estates were not on the market and could only be disposed of on an explicit iussum principis. ${ }^{7}$ The distinction that is being made here between imperial property that was freely transferable and other assets belonging to the emperor that were not is, indeed, inescapable. However, one should not be deceived by this. There is no indication of a fundamental legal difference between the various components of the

\footnotetext{
römischen Reiches in der hohen Kaiserzeit I (Basel 1995), 130-131. I should emphasise that this paper is only concerned with procurators serving as administrators of the imperial domain, the officials referred to since the third century (see Dig. 19.1 Rubr. and often in the imperial rescripts reported in the Codex Theodosianus and Codex Justinianus) as rationales. I have avoided the concepts 'fiscal' or 'financial' procurators because these adjectives too strongly suggest activities confined to the imperial treasury department. Not all civil servants are (were) officials of the 'I(mperial) R(evenue) S(ervice)'.

${ }^{5}$ The seminal studies are S. Schlossmann, Der Besitzerwerb durch Dritte nach römischem und gemeinem Recht (Leipzig 1881) and Die Lehre von der Stellvertretung (Leipzig 1900/1902), and more recently A. Claus, Gewillkürte Stellvertretung im römischen Privatrecht (Berlin 1973). See further M. Kaser, Das römische Privatrecht I (München 1971), 265, 587; O. Behrends, 'Die Prokuratur des klassischen römischen Zivilrechts', Zeitschrift der Savigny Stiftung 88 (1971), 215 ff;; A. Burdese, 'Sul Procurator', Studia et Documenta Historiae et Iuris 37 (1971), $307 \mathrm{ff}$; J. Plescia, 'The Development of Agency in Roman Law', Labeo 30 (1984), 171 ff., and Chr. Schäfer, Spitzenmanagement in Republik und Kaiserzeit (St. Katharinen 1998), all with extensive further literature.

${ }^{6}$ See some general observations in E. von Herzog, Geschichte und System der römischen Staatsverfassung II, Abt. 2, System der Verfassung der Kaiserzeit (Leipzig 1891 [repr. Aalen 1965] ), 670; Hirschfeld 1905, op.cit. (n. 4), 411 and P.R.C. Weaver, Familia Caesaris (Cambridge 1972), 267. ${ }^{7}$ Dig. 30.39.10 i.f.
} 
imperial domain, as has been supposed by many a commentator. From the perspective of private law, the entire imperial domain, the imperial fiscus in the broadest sense of that concept, was private property. ${ }^{8}$ Of course, everyone knows Ulpian's famous statement that 'res fiscales' are 'quasi propriae et privatae principis' ${ }^{\text {, }}$, but some attention should be paid to the context of that famous statement.

In the $68^{\text {th }}$ book of his commentary on the Edict, Ulpian comments on the interdictum 'Ne quid in loco publico vel itinere fiat'. This was an interdictum populare, enabling the public at large to apply for an injunction against, for example, unauthorised building activities on public property. The interdictum did not apply to such activities on privately owned land, nor on land belonging to the imperial fiscus: 'hoc interdictum ad ea loca, quae sunt in fisci patrimonio, non puto pertinere'. ${ }^{10}$ As far as Ulpian was concerned, the reason for this was simple: real estate of the emperor was his private property. If the public made use of it, for example by way of footpath or road, it did so at the emperor's discretion and if someone obstructed these activities, it was the emperor, not the public, who had a cause of action against the trespasser. Ulpian emphasises that in such a case a complaint should be filed with the imperial procurator in charge of the land concerned.

As far as I know, Ulpian's statement contains practically the only contemporary dictum on the legal quality of imperial property. It is reinforced by Seneca's no less well-known statement that the fiscus is part of the emperor's private property $($ ' $<$ Caesar habet $>$ fiscum ac privata sua in patrimonio proprio'). ${ }^{11}$

As with Ulpian's statement, the context of Seneca's dictum is significant. He tries to clarify that a thing may belong to different people in different ways at one and the same time. He uses a lease of a house as an example. 'When I rent your house, I acquire a title to the house concurrent with yours', he says. ${ }^{12}$ And so it is in all instances, where an owner grants a right of enjoyment. On a different level, it is the

\footnotetext{
${ }^{8}$ Mommsen 1952, op.cit. (n. 4), II.2, 998 ff; Kaser 1971; op.cit. (n. 5), I, 305 f.; II, 152. The nature of the imperial fiscus and its relation to the imperial patrimonium and res privata have been the subject of a prolonged scholarly dispute. I refer to the dispute between Mommsen (1.c.) and Hirschfeld 1905, op.cit. (n. 4), 1 ff.; Hirschfeld, op.cit., 21 ff and O. Karlowa, Römische Rechtsgeschichte I (Leipzig 1885), 505 ff; F. Millar, 'The Fiscus in the First Two Centuries', Joumal of Roman Studies 53 (1963), $29 \mathrm{ff}$., and P.A. Brunt, 'The Fiscus and its Development', Joumal of Roman Studies 56 (1966), $75 \mathrm{ff}$. (now in Idem, Roman Imperial Themes [Oxford 1990], 134 ff.). See also H. Nesselhauf, 'Patrimonium und res privata des römischen Kaisers', Historia Augusta Colloquium 1963 (1964), 73 ff.

${ }^{9}$ Dig. 43.8.2.4.

${ }^{10}$ Dig. 43.8.2.4.

${ }^{11}$ De Beneficiis 7.6.3.

${ }^{12}$ De Beneficiis 7.5.2.
} 
same with a monarch: 'under a good king, all things belong to him on account of his superior title as sovereign, but they belong to private individuals as well on account of their ownership of it ${ }^{13}$ On the same lines, it may be said of Caesar, that he owns everything on account of his superior position in the state ('Caesar omnia habet'). However, as a citizen he merely owns what belongs to him in his private capacity, i.e. the fiscus and his private property ('fiscum ac privata sua').

So, as far as private law was concerned, there were no significant differences between the various components of the imperial domain. The only thing that counted for the lawyers was the person responsible for their administration. Hence Ulpian's reference to the imperial procurator in charge of land that was being encumbered by trespassers and hence his reference to the procurator patrimonii in connection with parts of the imperial domain that were not, as a rule, for sale. He does not indicate certain specific parts of the imperial domain, but merely refers to property under the administration of one particular procurator, the procurator patrimonii. All it really meant is that the procurator patrimonii had no authority to dispose of the land assigned to his administration. Other imperial procurators, however, might have that authority as a matter of course. It all depended on the extent of their administratio, the powers donated to them by the emperor. I believe that at this point an example from Roman private law is helpful.

Slaves carrying on business as grantees of a peculium were the Roman equivalent of modern companies. ${ }^{14}$ In granting a peculium to his slave, the master had in fact created what amounts to a modern company with limited liability. Though formally and technically still a part of the estate of the master, in fact - and to a certain extent even at law - the peculium had become a special fund separated from the rest of the estate of the master. In this way, different peculia could be segregated from the estate of the master, all of them in the care and under the administration of different servi peculiarii.

In as far as the liabilities incurred by the master himself were concerned, the fragmentation of his estate into various separate funds was immaterial. They all belonged to his estate and were liable to be sold in execution of his private debts.

\footnotetext{
${ }^{13}$ De Beneficiis 7.5.1.

${ }^{14}$ See my article 'Callistus's Case' in L. de Blois and J. Rich, eds., The Transformation of Economic Life under the Roman Empire. Procceedings of the Second Workshop of the International Network Impact of Empire (Roman Empire, 200 B.C. - A.D. 476) (Amsterdam 2002), 116-127. On peculium generally see A. Kirschenbaum, Sons, slaves and freedman in Roman commerce (Jerusalem 1987); I. Zeber, A Study of the peculium of a Slave in Pre-Classical and Classical Roman Law (Wroclaw 1981) and J.J. Brinkhof, Een studie over het peculium in het klassieke Romeinse recht (Meppel 1978 [containing a résumé in German] ).
} 
Hence there is no reference to them whenever the liquidation of the master's estate is under discussion. So the fragmentation of an estate into various peculia was only of importance to the persons doing business with the slave administering a part of it. As far as the master and his personal creditors were concerned it was irrelevant. The parallel with the imperial domain should be obvious. The fragmentation of the imperial domain into separate funds (fiscus, patrimonium and - after Septimius Severus - res privata) was irrelevant as far as the emperor and his successors were concerned. It was only relevant to private individuals doing business with the officials administering the various departments.

Many slaves, especially those to whom a libera administratio of their peculium had been granted, were authorised to dispose of the assets belonging to it without ratification by their master:

Ulpianus, libro septimo decimo ad edictum: si servus mihi vel filius familias fundum vendidit et tradidit habens liberam peculii administrationem, in rem actione uti potero. sed et si domini voluntate domini rem tradat, idem erit dicendum: quemadmodum cum procurator voluntate domini vendidit vel tradidit, in rem actionem mihi praestabit. $^{15}$

In explaining these general principles, Ulpian refers to the administration by common procurators, who were also entitled to dispose of their principal's property, provided they were authorised to do so. It was the same with imperial procurators: some of them, having a libera administratio, were entitled to dispose of the property assigned to their administration and some were not, unless they were specifically authorised to do so. Of course, this allocation of functions did not affect the legal status of the estate of the emperor as such, but in dealing with one of the imperial procurators, it was important to know if he was authorised to dispose of the assets under his control. It has been noted that the Romans themselves (and notably among them the lawyers) were not as preoccupied with the question concerning the relationship among the various imperial 'treasuries' as modern scholars are. ${ }^{16}$ The reason is that, to them, the emphasis was on the powers of the procurator in charge, rather than on the legal quality of the assets assigned to him. To a Roman lawyer, the question whether or not the estates under the control of the procurator patrimonii were to be qualified as "Krongut" (Hirschfeld), would have been quite futile. What counted to him, was that that particular procurator did not have a libera administratio of the property

\footnotetext{
${ }^{15}$ Dig. 6.1.41.1.

${ }^{16}$ See, for example, R. MacMullen, 'Two Notes on Imperial Properties', Athenaeum 54 (1976), 24.
} 
assigned to him. Valerius Patruinus clearly was authorised to dispose of the imperial estates under his control. However, his position was quite different from that of an ordinary procurator. He was not a mere caretaker, but a representative of the emperor, a civil servant rather than a common agent. In fact, I believe that the fundamental changes brought about by Papinian in the Roman law of agency were, at least partially, inspired by the peculiar position of an imperial procurator.

Before Papinian revolutionised the Roman law of agency by making the principal accountable as well, ${ }^{17}$ it was the procurator, rather than his principal, who was personally liable on account of all contracts he had made on behalf of his employer. ${ }^{18}$ There is some evidence that, at least initially, it was the same with imperial procurators.

In A.D. 23 the inhabitants of the province of Asia sued the imperial procurator Lucilius Capito. True as it may be, that he was accused of gross abuse of his powers and consequently may have faced criminal charges, ${ }^{19}$ Dio Cassius adds a general statement on imperial procurators in his account of this incident, emphasising that in those days officials administering the imperial funds ... had to stand trial in the forum $\ldots$ on an equal footing with ordinary citizens' ${ }^{20}$

Consequently all contracts concluded by an imperial procurator in the name of the emperor were initially - in fact, as well as at law - contracts concluded with a private individual, i.e. the imperial procurator. There was no right of recourse to the emperor himself. It should be emphasised that this was not some peculiar device conceived in order to protect the emperor from incurring personal liability on account of all contracts concluded in his name, but a mere consequence of the fact that Roman law still lacked a fully developed law of agency. So the issue was not whether a procurator could bind his principal in contract (until Papinian's time he never could), but

\footnotetext{
${ }^{17}$ Dig. 14.3 .9 pr.

${ }^{18}$ On the strength of the famous maxim "per liberam personam, quae neque iuri nostro subiecta est neque bona fide nobis servit, obligationem nullam adquirere possumus" (Dig. 45.1.126.2 [Paulus] ). Add Dig. 13.7.11.6 (Ulpianus): "et ideo ipsi (scl. procuratores) convenientur". Possession and ownership, however, were acquired by the principal as a matter of right: Dig. 41.1.13 pr. (Neratius). On this: A. Watson, 'Acquisition of Possession per extraneam personam', Tijdschrift voor Rechtsgeschiedenis 29 (1961), 22 ff., and 'Acquisition of Ownership by 'traditio' to an 'extraneus', Studia et Documenta Historiae et Iuris 33 (1967), $189 \mathrm{ff}$.

${ }_{19}$ Possibly he was charged with the crime of vis, as P.A. Brunt, 'Charges of Provincial Maladministration', Historia 10 (1961), 189 ff, now in Brunt 1990, op.cit. (n. 8), 57 ff., suggested.

${ }^{20}$ Cassius Dio 57.23.5 and compare this statement to Dio's account of the functions of an imperial procurator in $53.15 .3 \mathrm{ff}$. On the incident see also Tacitus, Annals 4.15
} 
whether he could pass a good title to his contracting party. It was on account of this that it was usual to stipulate that the principal would ratify the dispositions of his agent (stipulatio rem ratam dominum habiturum) ${ }^{21}$ If the principal did, the transferee was assured of his title. If he did not, the transferee could sue the procurator on the strength of his guarantee. Imperial procurators did not have to give this kind of personal guarantee. Ulpian stresses this in a rarely commented fragment from the sixteenth book of his commentary on the praetorian Edict:

Ulpianus, libro sexto decimo ad Edictum: quae acta gestaque sunt a procuratore Caesaris, sic ab eo comprobantur, atque si a Caesare gesta sunt. ${ }^{22}$

An imperial procurator was a representative of the imperial administration with a carefully defined instruction, indicating the scope of his authority. ${ }^{23}$ In entering into a contract with a procurator Asiae for the sale of some land, it was of course well understood that - if at all - he was exclusively authorised to dispose of imperial estates within his province and only if they were not (as they might well be) under the direct control of the procurator patrimonii in Rome, or one of his local representatives.

In his account of the Lucilius Capito incident Tacitus quotes Tiberius as saying 'that he had given <Capito> no other powers than over his household and his property' (non se ius nisi in servitia et pecunias familiares dedisse [Annals 4.15] ). Lucilius Capito was acting as manager (procurator) of the imperial private interests in the province of Asia, which had a senatorial governor. Tacitus's remarks suggest that the powers of a provincial procurator, such as Capito, may have been merely of an administrative nature, not necessarily including powers of sale. In the little poem to Silvanus by T. Pomponius Victor, an imperial procurator and governor in the Alpes Graiae, the poet describes his office as 'to adjudicate and to look after the interests of the emperors' (ius gubernare et rem fungi Caesarum (ILS 3528)). Victor was a provincial governor (with the title of procurator) and therefore a judge, but he was also the caretaker of the patrimonial interests of the emperor in the province, i.e. he was a 'managerial' agent as well. The way in which he describes the latter

\footnotetext{
${ }^{21}$ Dig. 46.8.10.

${ }^{22}$ Dig. 1.19.1 pr. As the context clearly shows, the fragment does not refer to the jurisdiction conferred on some imperial procurators, as G. Urögdi (RE Suppl. X [1965] s.v. 'procurator fisci') implies. P.A. Brunt, 'Procuratorial Jurisdiction', Latomus 25 (1966), 461 ff. (now in Brunt 1990, op.cit. [n. 8], 163 ff., 177), suggests that Ulpian refers to 'executive decisions' (?) of imperial procurators. The truth is that the text merely refers to the powers of disposition over imperial property granted to a procurator.

${ }^{23}$ H.-G. Pflaum, Les procureurs équestres sous le Haut-Empire romain (Paris 1950), 5. Cp. Cassius Dio 53.15.4.
} 
aspect of his duties also suggests limited powers with respect to the imperial property within his province. ${ }^{24}$

In dealing with a local procurator vicesimae hereditatium ( a mere agent of the imperial revenue service), a sale or lease of imperial estates by that official was clearly ultra vires. The procurator hereditatium, on the other hand, is a good example of an important imperial procurator who must have had a libera administratio of the property under his control. It was his task to make an inventory of all the inheritances that were bequeathed to the emperor, ${ }^{25}$ pay the outstanding debts of the testator, ${ }^{26}$ assign the parts that were worth keeping to other departments of the imperial household, for example the procurator patrimonii, ${ }^{27}$ and to sell the parts that were not. He must have been an important player on the Roman real estate market and Valerius Patruinus may well have been acting in this capacity when selling a vineyard to Stalticius. It is with activities of this kind that the special position of an imperial procurator emerges. In disposing of parts of the estate, the procurator ran the risk of mistakenly selling property that did not belong to the testator. He may, for example, have believed that a piece of land belonged to the testator, whereas in fact it had been leased to the testator. ${ }^{28}$ In ordinary sales of this kind, it was usual that the buyer stipulated for a personal guarantee against 'eviction', that is a judgement under which the buyer had to give up the land to the real

\footnotetext{
${ }^{24}$ See Ulpian's opinion on a procurator selling and transferring imperial property in his own interest in Dig. 1.19.1.1: "Si rem Caesaris procurator eius quasi rem propriam tradat, non puto eum dominium transferre: tunc enim transfert, cum negotium Caesaris gerens consensu ipsius tradit. denique si venditionis vel donationis vel transactionis causa quid agat, nihil agit non enim alienare ei rem Caesaris, sed diligenter gerere commissum est" (for it is not his charge to dispose of the emperor's property, but to administer it diligently [italics added] ).

${ }^{25}$ If the estate of the testator was found to be insolvent, the emperor had to be consulted in person to find out whether he still wanted to accept the inheritance. See Dig. 1.19.2 (Paulus): "heredis enim instituti in adeundis vel repudiandis huiusmodi hereditatibus voluntas exploranda est". The implication is that the procurator hereditatium was authorised to accept a solvent inheritance in the name of the emperor without further consultation. It is even reported that a procurator (hereditatium) could instruct one of the slaves employed in his department to accept an inheritance on the emperor's behalf (Dig. 1.19.1.2 [Ulpianus] ).

${ }^{26}$ Dig. 49.14.11 (lavolenus).

${ }^{27}$ There is a close relationship between the department of the procurator patrimonii and the department of the procurator hereditatium. Originally the procurator patrimonii seems to have been in charge of the winding up of inheritances left to the emperor. The important office (he was a ducenarius) of procurator hereditatium only became an independent branch of the civil service after bona caduca et vacantia were assigned to the imperial fiscus rather than the aerarium populi Romani. See Hirschfeld 1905, op.cit. (n.4), $114 \mathrm{ff}$.

${ }^{28} \mathrm{He}$ may also easily have missed the fact that an estate bequeathed to the emperor had been leased by the testator. In fact this is what I believe has happened in the case at hand
} 
owner. It was usually for double the price (stipulatio duplae). Of course, one would expect the same kind of guarantee to be given by an imperial procurator, but it is explicitly stated that, on eviction, the fiscus would only pay back the price to the buyer, whatever the procurator had guaranteed:

Ulpianus, libro sexto decimo ad Edictum: si <pro>curator Caesaris rem aliquam vendiderit, quamvis duplum vel triplum pro evictione promiserit, tamen fiscus simplum praestabit. ${ }^{29}$

It is a well-known fact that Marcus Aurelius took special interest in sales by his fiscal officials, notably in the position of a buyer, who was in danger of being evicted by a potential owner. ${ }^{30} \mathrm{He}$ also instructed his procurators on the price-fixing of the assets they sold and urged them to act in good faith and with due diligence. ${ }^{31}$ All these provisions presuppose that the emperor assumed responsibility for the engagements of his procurators acting within the scope of their authority. It meant nothing less than that the fiscus as such assumed liability for those acts. This affected the legal status of the imperial procurators. They had ceased to be mere agents acting in a private capacity and had become officials representing the emperor as head of state. ${ }^{32}$ Public rather than private law defined their position. Some (certainly not all) 'managerial' procurators were even granted original jurisdiction within the sphere of their competence. ${ }^{33}$ It is not improbable, even likely, that Valerius Patruinus's case originated in a dispute between Stalticius and the farmer of the vineyard that he himself had been called upon to decide.

The importance of the judicial functions of 'administrative' or 'managerial' procurators may easily be overestimated. They were minor magistrates within the Roman judiciary: they had no jurisdiction in ordinary civil cases ${ }^{34}$ and no criminal

\footnotetext{
${ }^{29}$ Dig. 49.14 .5 pr. Does it follow from this that the fiscus guaranteed the return of the price, even when the procurator had excluded liability for eviction?

${ }^{30}$ G. Klingenberg, 'Das Edictum divi Marci de rebus alienis a fisco distractis' in Revue Internationale des Droits de l'Antiquité 34 (1987), $181 \mathrm{ff}$.

${ }^{31}$ Dig. 49.14.3.5 (Callistratus). Cp. A. Birley, Marcus Aurelius (London 2000), 49.

${ }^{32}$ H.-G. Pflaum, 'La mise en place des procuratèles financières dans les provinces du Haut-Empire romain' in Revue Historique de Droit Français et Étranger 46 (1968), 387: 'Cette évolution de la titulaire correspond exactement à une mutation dans les rapports entre le souverain et ses fondés de pouvoir. Alors qu'au début du principat ceux-ci se considéraient eux-mêmes comme étant au service du prince en tant qu'homo privatus, ils ont avec le temps qui passe de plus en plus conscience d'être au service de l'empereur en tant que magistrat suprême de l'État romain'.

${ }^{33}$ Mommsen 1952, op.cit. (n. 4) II 2, 1021 ff.; Pflaum 1950, op.cit. (n. 23), 152 f; Brunt 1990, op.cit. (n. 8), $163 \mathrm{ff}$.

${ }^{34}$ Dig. 49.1.23.1 (Papinianus).
} 
jurisdiction over capital offences. ${ }^{35}$ As it seems to me, they were only authorised to hear cases directly concerning the administration of the imperial property under their control. Good examples are complaints against someone encumbering imperial estates to the prejudice of the public making use of it, ${ }^{36}$ or against someone trespassing on imperial property rented to coloni. ${ }^{37}$ They also decided cases concerning the rent of imperial property. In all these instances there was, indeed, an encroachment on the original jurisdiction of the praetor (in Rome), or the praeses provinciae. It may well be that Claudius's much discussed ${ }^{38}$ grant of original jurisdiction to imperial procurators was merely concerned with cases like these. ${ }^{39}$

So, long before the imperial domain itself was at last recognised as public property, ${ }^{40}$ the imperial officials in charge were already recognised as civil servants acting in a public rather than a private capacity. Consequently, in the days of Cassius Dio the individual procurator who had incurred a liability of the fiscus had ceased to be personally accountable, as he may still have been in the days of Tiberius. In case of a dispute an imperial procurator was not allowed to decide in his own right, the interests of the emperor were taken out of his hands and taken over and managed by an advocatus fisci, or a representative of the procurator a rationibus. ${ }^{41}$ Maybe this is the reason why, contrary to current ideas, ${ }^{42}$ advocati fisci were usually seasoned administrators rather than highly trained lawyers.

\section{Valerius Patruinus's case}

It is clear from all we have established, that Valerius Patruinus's efforts were not to avoid his own personal liability, but to minimise the liability of the imperial fiscus. ${ }^{43}$ His own responsibility was never an issue; had it been, the imperial consilium would not have hesitated to make him personally accountable to the tenant of the vineyard. If only because in doing so it would have avoided considerable legal problems. The fact that it did not even raise the issue proves even more so that Patruinus's personal liability

\footnotetext{
${ }^{35}$ Dig. 1.19.3 pr. (Callistratus) and CJ 3.26.1 (Severus and Caracalla).

${ }^{36}$ Dig. 43.8.2.4 (Ulpianus).

${ }^{37}$ Dig. 1.19.3,1 (Callistratus).

${ }^{38}$ See, for example, Brunt 1990, op.cit. (n. 8), 163 ff.; B. Levick, Claudius (London 2001), 50 and W. Eck, Die Verwaltung des römischen Reiches in der hohen Kaiserzeit II (Basel/Berlin 1998), $161 \mathrm{ff}$.

${ }^{39}$ As was suggested by F. Millar, 'Some Evidence on the Meaning of Tacitus, Annals 12.60', Historia 13 (1964), 180 ff. at 187, but see Brunt 1990, op.cit. (n. 8), $168 \mathrm{ff}$.

${ }^{40}$ By the emperor Zeno: see CJ 4.37.2 (sacratissimum aerarium).

${ }^{41}$ M. Kaser \& K. Hackl, Das römische Zivilprozessrecht (München 1996), 455.

${ }^{42}$ See the rather disappointing lemma 'advocatus' in Der Neue Pauly: "Als Kenner des Rechts fungierten offenbar die von Hadrian eingesetzten advocati fisci".

${ }^{43}$ Cf. Dig. 49.14.50: "ne fiscus colono teneretur" (italics added).
} 
was out of the question. ${ }^{44}$ Failing that possibility, the question was now how to meet the legitimate interests of the farmer without embarrassing the fiscus.

Patruinus's problem was submitted to the imperial consilium, maybe because he felt that he was personally too much involved and should leave the decision to a superior instance. The emperor - Septimius Severus - presided. His praefectus praetorio Aemilius Papinianus, the famous lawyer, and some of his assistants joined him in deciding the case.

The report in the Digests ${ }^{45}$ of this session of the imperial 'privy council' contains a rare example of the reliability of at least some of the information in the vita of Pescennius Niger. It is reported in the third book of Paul's 'Imperial Decisions' and it is said in that vita that Paul was a member of Papinian's consilium. ${ }^{46}$ Most (if not all) imperial decreta reported by Paul are from this period in his career. ${ }^{47} \mathrm{He}$ had the rare privilege of an insight into the working of the administrative machinery and was kind enough to share it with the public.

Besides Papinian and Paul, there were two more famous lawyers participating, Claudius Tryphoninus and Publius Messius Saturninus. ${ }^{48}$ Paul does not mention another assistant of Papinian, Domitius Ulpianus, ${ }^{49}$ but he did not take to his colleague at all and may simply have ignored him. So it was quite a gathering of legal expertise deciding the case. Paul, never at a loss to express his disapproval of sloppy legal reasoning, did not like what came out of it. 'Papinian and Messius', he writes, 'came up with something new' ${ }^{50}$ It was decided to leave the tenant in possession of the vineyard for the duration of his term and assign the rent to Stalticius. It was, indeed, novum ius - to a Roman lawyer tantamount to bad law - but very expedient to the fiscus.

\footnotetext{
${ }^{44}$ If the land concerned had been bequeathed to the emperor by will and the lease to the farmer had been granted by the testator beforehand, the liability would have been with the fiscus, not the procurator, as a matter of course. The fact that this legal nicety was not even considered strongly confirms that the liability of the fiscus was taken for granted in any case.

${ }^{45}$ Dig. 49.14 .50 (Paulus, libro tertio Decretorum).

${ }^{46}$ SHA, Niger 7.4. See also Alexander Severus 26.6.

${ }^{47}$ On Paul's reports of imperial decreta see Fr. Schulz, Roman Legal Science (Oxford 1963), 154.

${ }^{48}$ On these two lawyers see W. Kunkel, Herkunft und soziale Stellung der römischen Juristen (Graz/Cologne 1967), $231 \mathrm{ff}$. and $229 \mathrm{ff}$.

${ }^{49}$ On Ulpian as assistant to Papinian see SHA, Niger 7.4.

${ }^{50}$ Dig. 49.14.50: "Papinianus et Messius novam sententiam introduxerunt".
} 


\section{Conclusion}

It has been the official doctrine of the Roman emperors for a very long time that, as Augustus put it, they 'excelled all in dignity but possessed no more power than those who were their colleagues in any magistracy'. ${ }^{51}$ It has been shown long ago that this doctrine collapses under the sheer weight of the ubiquitous monarchical representation of imperial power in Rome and the empire at large. Imperial representation by procurator is only one of the aspects of the all but private character of the emperor's position. Imperial power was very unlike the powers wielded by common magistrates, if only because the emperor had been granted the tribunicia potestas for life. ${ }^{52} \mathrm{It}$ provided personal immunity from persecution in any court, including the civil courts. ${ }^{53}$ True it is that an ordinary consul, praetor or tribunus plebis was also immune, but only during his term of office. After that, he could be sued like any other private individual. ${ }^{54}$ Only the emperor could never be summoned in person: he was sacrosanctus.

Tacitus emphasises that Tiberius allowed civil suits to be brought against him. ${ }^{55}$ Of course, this does not mean that the emperor ever appeared in court as a defendant or even a plaintiff. In doing so, he would have submitted his imperium maius and his tribunicia potestas to the lesser powers of a praetor. Such an act of public humiliation was constitutionally unthinkable. It would have affronted the dignitas of the emperor personally, as well as the office of all magistrates cum imperio and tribuni plebis. Unlike any private individual, the emperor always had to be represented by a procurator, an attorney acting on his behalf. A correct evaluation of the peculiar position of an imperial 'administrative' procurator has to be based on this assessment. It set them apart from ordinary procurators. In the early days of the principate these imperial procurators may still have been personally liable on account of all transactions on behalf of the emperor, but this must have ceased after the character of imperial representation by procurator was changed for good by Domitian, Trajan and Hadrian. ${ }^{56}$ It had ceased to be a service rendered to the emperor in person for free and on an incidental basis

\footnotetext{
${ }^{51}$ Res Gestae Divi Augusti 34.3.

${ }^{52}$ Res Gestae Divi Augusti 10.1 .

${ }^{53}$ On the immunity of magistrates cum imperio and of tribuni plebis see Dig. 4.6.26.2, 47.10.32 and 48.2.8. Cp. Mommsen 1952, op.cit. (n. 4) I, 706 and II, 297-298.

${ }^{54}$ This seems to have been the reason why Caesar, after having been appointed propraetor in Spain, departed for his province while still a praetor: Suetonius, Divus Iulius 18.

${ }^{55}$ Annals 4.7: "ac si quando cum privatis disceptaret: forum et ius".

${ }^{56}$ On the changes effected in the procuratorial administration by these emperors see H.-G. Pflaum, RE XXIII (1), s.v. 'procurator', 1244-1245.
} 
and had become a salaried office. As long as they acted within the scope of their authority, these imperial officials were personally unaccountable for their engagements on behalf of the emperor. All civil responsibility was with the imperial fiscus as such. It may well be that the idea of the fiscus as a 'private estate serving a public purpose ${ }^{, 57}$ originated in the understanding that the officials acting on behalf of it were public servants rather than private agents. Ulpian, for one, must have realised this. That is why he defined the imperial domain as ' $<$ res $>$ quasi propriae et privatae principis'.

As far as Valerius Patruinus is concerned, my guess is that he was a procurator hereditatium at one time in his career before ultimately becoming a praefectus praetorio. He was murdered in 212, as were Papinian and other loyal servants of Severus and Geta. As a Roman, an experienced administrator and (as I like to believe) a stoic, he must have known that services rendered are usually unforgiven.

Leiden, February 2002

\footnotetext{
${ }^{57}$ On this definition see A. Brinz, 'Über die rechtliche Natur des römischen Fiscus' in Sitzungsberichte der Bayerischen Akademie 1886, $471 \mathrm{ff}$.
} 